6. Oleynik G.N. Structure and functioning of bacterioplankton and bacteriobenthos in the water bodies with high content of inorganic nitrogen / G.N. Oleynik, Ye.V. Starosila // Hydrobiol. J. 2010. V. 46, N 6. P. 26-36.

7. Romanenko V.D. Method of complex assessment of the bottom sediments toxicity using benthic and planktonic organisms / V.D. Romanenko, M.T. Goncharova, I.N. Konovets et al. Hydrob. J. 2012. V. 48, № 2. P. 30-39.

DOI https://doi.org/10.30525/978-9934-26-006-3-15

\title{
ПОШУК ПОТЕНЦЙНО РЕФЕРЕНЦІЙНИХ ДІЛЯНОК ДЛЯ ВИЗНАЧЕННЯ ЕКОЛОГІЧНОГО СТАНУ БАСЕЙНУ РІЧКИ ВІСЛА
}

\author{
Лстицька О. М. \\ кандидат біологічних наук, \\ старший науковий співробітник відділу іхтіології \\ та гідробіології річкових систем \\ Інститут гідробіології Національної академії наук України \\ Кіпніс Л. С. \\ кандидат біологічних наук, \\ старший науковий співробітник відділу екологічної фізіології \\ гідробіонтів та біотехнології \\ Інститут гідробіології Національної академії наук України \\ Гончарова М. T. \\ кандидат біологічних наук, \\ старший науковий співробітник відділу екологічної фізіології \\ гідробіонтів та біотехнологіі \\ Інститут гідробіології Національної академії наук України \\ м. Київ, Украӥна
}

Згідно з Водною рамковою директивою (ВРД) ЄС 2000/60, «екологічний стан - це вираження якості структури і функціонування водних екосистем», де пріоритетними показниками є структурні та функціональні характеристики угруповань гідробіонтів, як дескрипторів екологічного стану річок. Для оцінки та класифікації екологічного стану масивів поверхневих вод, першим кроком $€$ встановлення 66 
типоспецифічних (референційних) умов та виявлення ділянок, де збереглася природна структура біологічних угруповань та відсутній або не реєструється доступними методами антропогенний вплив.

Виділення референційних ділянок базується на діалектичному підході, при якому русло і заплава річки визначаються як єдина водна екосистема, що, згідно з ВРД ЄС, є масивом поверхневих вод. Зазвичай відмінний екологічний стан (еталоні умови) спостерігається в непорушених природних екосистемах, а встановлення потенційних референційних ділянок масивів поверхневих вод району басейну відповідає умовам впровадження «Порядку здійснення державного моніторингу вод», затвердженого постановою Кабінету Міністрів України № 758 від 19.09.2018 та передбачено вимогами ВРД ЄС.

Територія басейну річки Вісла на українській частині знаходиться в межах двох областей - Львівської та Волинської, має 20 типів масивів поверхневих вод (МПВ), що належать до двох екорегіонів: № 10 Карпати та № 16 Східні рівнини. Площа басейну річки Вісла в межах

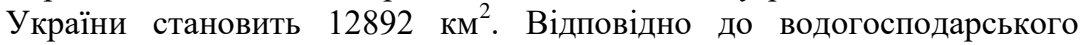
районування басейн річки Вісла складається $з$ двох суббасейнів річок: Західний Буг та Сян. Перед кордоном з Республікою Білорусь у басейні Західного Бугу розташована унікальна група Шацьких озер, які входять до Шацького національного природного парку, який входить до складу Транскордонного біосферного резервату «Західне Полісся».

Метою роботи був пошук референційних ділянок для визначення екологічного стану МПВ басейну Вісла, що в перспективі надасть можливість встановлення референційних значень для всіх біологічних елементів якості відповідно до ВРД (фітопланктон, фітобентос, інша водна флора, макробезхребетні та риби).

Актуальність роботи полягає у необхідності визначення потенційних референційних ділянок басейну Вісли, що відповідає умовам впровадження «Порядку здійснення державного моніторингу вод», для розробки Плану управління річковим басейном для досягнення екологічних цілей.

Матеріали та методи досліджень. Комплексні гідроекологічні дослідження проводились в літньо-осінній період 2020 р. Проби води та донних відкладів відбирали стандартними методами [1]. Гідрохімічний аналіз води виконували за [1], а оцінку якості - згідно 3 екологічною класифікацією [2].

Оцінка токсичності здійснювалась методами біотестування на тесторганізмах різних трофічних рівнів. Проби води досліджували на токсичність протягом 48 годин на гіллястовусих ракоподібних 
Ceriodaphnia affinis Lilljeborg, зелених водоростях Desmodesmus communis за 72 год експозиції, а також на рясці малій Lemna minor L. протягом 14 діб [3]. Для оцінки токсичності донних відкладів аналізували водні витяжки донних відкладів за допомогою Daphnia magna Straus та L. minor та «цільні» донні відклади комплексним методом [3] протягом 10 діб на Chironomus riparius Meigen та D. magna. Узагальнення результатів біотестування проводили за [3].

Генотоксичність води та донних відкладів оцінювали за допомогою мікроядерного тесту, рівня мітотичної активності та аберантних хромосом в кореневій меристемі Allium сера L. [3].

Відбір гідробіологічного матеріалу здійснювали за всіма блоками (фітопланктон, фітобентос та інша флора, донна фауна, а також іхтіофауна), відповідно до Постанови КМУ № 758 від 19 вересня 2018 р. «Про затвердження Порядку здійснення державного моніторингу вод» та вимог ВРД. Для кожної станції заповнювалась форма «Польового протоколу...» [4], поряд 3 біотопічним описом ділянки враховували водовикористання, наявність видимих забруднень русла і заплавних територій.

Результати досліджень. В річковому басейні Вісли в межах України було досліджено всі виділені типи МПВ, як озера, так і річки з метою встановлення потенційно референційних ділянок, які зберегли свої природні ознаки чи мали незначні порушення в гідроморфологічному аспекті, всього було обстежено понад 40 ділянок МПВ, з яких: річки суббасейну Сяну - Ріка, Раків, Вишня, Потік Зелений, Малий Гноїнець, Ретичи, Віжомля, Шкло; в суббасейні Західний Буг саму річку вище населених пунктів: Колотов, Білий Камінь, Петричі, Волиця Деревлянська, Тадани, Кам'янка Бузька, Городище, Старгород та іiї притоки - p. Білостік, р. Без Назви та р. Рата. Також було досліджено групу Шацьких озер - Чорне Велике, Велике Піщанське, Перемут, Люцимер, Пісочне, Світязь та Пулемецьке.

За результатами гідрохімічного аналізу за більшістю трофосапробіологічних критеріїв вода досліджених ділянок р. Західний Буг належала до класів IV-V «погані»-»дуже погані», характеризувалась підвищеним вмістом сполук азоту, особливо його найбільш токсичної нітритної форми, та азоту амонійного, особливо на ділянках вище с. Волиця Деревлянська, вище с. Тадани та околиці м. Камянка-Бузька. За екологічною класифікацією якість води цих ділянок за вмістом біогенних речовин та величиною ХСК та БСК 5 відносилась до класу V.7 «дуже погані, дуже брудні». Серед всіх досліджених ділянок р. Західний Буг можна виділити найбільш чисті - біля с. Колотов та с. Білий камінь, вище с. Старгород та притоку р. Білостік, вода яких за 68 
більшістю трофо-сапробіологічних критеріїв відносилась до класу II.2 «добрі, досить чисті».

Серед річок суббасейну р. Сян найкращий екологічний стан за гідрохімічними показниками відмічений у р. Раків (верхня і середня течіï) та р. Ріка, клас якості II.2 «добрі, досить чисті».

Група Шацьких озер за величиною загальної мінералізації, яка не перевищує 300,0 мг/дм ${ }^{3}$ належать до прісних гіпогалинних водойм. За вмістом сульфатів та хлоридів вода всіх досліджених озер може бути охарактеризована як «добра, чиста». За трофо-сапробіологічними критеріями в групі Шацьких озер можна виділити найбільш чисті - оз. Велике Чорне, Пулемецьке, Пісочне та Велике Піщанське - вода яких переважно відносилась до класу II. 2 «добрі, чисті». Вода в озерах Світязь, Люцимер та Перемут відносилась до класу III.4 «задовільна, слабко забруднена».

За результатами біотестування, отриманими на тест-організмах різних систематичних груп, вода на переважній більшості ділянок річки Західний Буг була «помірно токсичною», окрім ділянок вище с. Волиця Деревлянська та притоки Рата, вище с. Сілець, вода яких відносилась до класу «токсична», що підтверджується і біологічними даними. В донних відкладах спостерігалась значно вища токсичність, порівняно 3 водою, на більшості станцій суббасейну Західного Бугу, вони були «токсичні», окрім ділянок біля с. Петричі, вище с. Городище, вище с. Старгород та притоки р. Білостік, де не спостерігалось токсичності. Не токсичними були і річки суббасейну Сян - Ріка та Раків.

За результатами біотестування можна виділити найбільш чисті озера, в яких не спостерігалось токсичності ні у воді, ні в донних відкладах: Пулемецьке, Перемут, Пісочне, Велике Піщанське, екологічний стан яких визначено як «добрий». В озерах Велике Чорне та Люцимер спостерігалась «токсичність».

У пробах води досліджених МПВ генотоксичності не виявлено, у пробах донних відкладів виявлена слабка генотоксична дія з ділянок p. Західний Буг вище с. Волиця Деревлянська, притоки р. Рата вище с. Сілець та озера Перемут.

Дана тенденція спостерігалась і за біологічною складовою, так досліджені ділянок річок Раків, Ріка та Потік Зелений (суббасейну Сяну) та p. Білостік (суббасейну Західного Бугу) відповідали «відмінному» стану. Річка Західний Буг та ії притока Рата було оцінено як - «задовільний» стан. Озера Велике Піщанське, Пісочне, Пулемецьке, Перемут та Люцимер, мали «відмінний»-»добрий» стан, а Світязь та Велике Чорне - «задовільний».

Висновки. Результати комплексних досліджень МПВ басейну Вісли на території України виявили практичну відсутність ділянок, які б мали 
стан близький до природного. Найбільш «чистими» та непорушеними масивами поверхневих вод, які можна розглядати як потенційні референційні є ділянки: Ріка та Раків (суббасейн Сяну); річка Білостік та озера Пулемецьке, Пісочне та Велике Піщанське в суббасейні Західного Бугу.

\title{
Література:
}

1. Методи гідроекологічних досліджень поверхневих вод / За ред. В.Д. Романенка. К.: Логос. 2006. 408 с.

2. Методика екологічної оцінки якості поверхневих вод за відповідними категоріями / В.Д. Романенко, В.М. Жукинський, О.П. Оксіюк та ін. К.: Символ-Т. 1998. 43 с.

3. Оцінка токсичності донних відкладів прісноводних об'єктів за допомогою біотестування / Гончарова М.Т., Кіпніс Л.С., Коновець I.М., Крот Ю.Г. Методичні рекомендації. Київ. 2019. 131 с.

4. Afanasyev S.O. Development of European approaches to biological assessment of the state of hydroecosystems and their application to the monitoring of Ukrainian Rivers. Hydrobiol. J. 2002. Vol. 38, N 4. P. 130-148.

DOI https://doi.org/10.30525/978-9934-26-006-3-16

\section{ОСНОВНІ АСПЕКТИ ЕКОЛОГІЧНОЇ ОСВІТИ ЗА СТАЛОГО РОЗВИТКУ В ОСВІТНЬОМУ ПРОЦЕСІ ЗВО}

\author{
Любинський О. I. \\ доктор сільськогосподарських наук, професор, \\ завідувач кафедри екологї
}

Кам'янеиь-Подільський національний університет імені Івана Огієнка м. Кам'янеиь-Подільський, Хмельницька область, Украйна

На початку третього тисячоліття в Україні відбувається становлення нової системи освіти, орієнтованої на входження до світового простору. Цей процес супроводжується історичними змінами в педагогічній теорії та практиці навчально-виховного процесу. Екологічна освіта, як цілісне культурологічне явище, повинна спрямовуватись на формування екологічної культури, екологізації навчальних дисциплін 